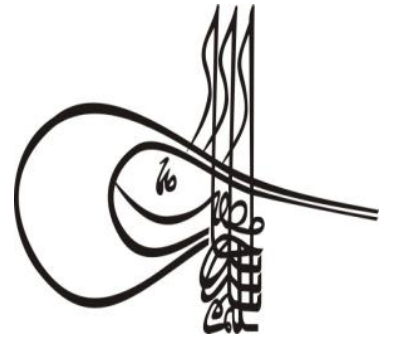

Received/Geliș: 22.06 .2019
Tutkigh Studies

Social Sciences

Volume 14 Issue 4, 2019, p. 1515-1523

DOI: 10.29228/TurkishStudies. 23388

ISSN: 2667-5617

Skopje/MACEDONIA-Ankara/TURKEY

Research Article / Araștırma Makalesi

Article Info/Makale Bilgisi

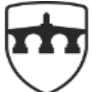

INTERNATIONAL BALKAN UNIVERSITY

EXCELLENCE FOR THE FUTURE IBU.EDU.MK

\title{
ESKİ ÇAĞ ÖN ASYA, ANADOLU VE AFRİKA UYGARLIKLARINA AİT GÜREŞ GÖRSELLERİNDE YER ALAN BENZERLİKLER VE FARKLILIKLAR
}

\author{
Mehmet IMAMOĞLU* - Gülten IMAMOĞLU $U^{* *}$
}

\begin{abstract}
öz
Bu çalışmada Eski Çağ Ön Asya, Anadolu ve Afrika uygarlıklarına ait güreş görsellerindeki benzerliklerin ve farklılıkların tespit edilerek incelenmesi amaçlanmaktadır.

Mezopotamya'da ortaya çıkarılan ve milattan önce yaklaşık 3000 y1lına ait olan resimlerde güreş yapan insanlar görülmektedir. Antik çağlardan itibaren bazı temalar, figürler ve karakterler birbirlerine çok benzer resmedilmiştir. Güress figürleri de bunlar arasında yer alır. Ön Asya'da ortaya çıkarılmış figürlerde güreşçilerin bazıları bellerinde kemerleri ile bazıları ise kemersiz resmedilmiştir. Ksanthos Güreşçiler Kabartması ve Isinda Mezar Dikmesi Güreşçi figürleri birbirlerine benzemektedir. Figürlerdeki güreşçiler iri yapılı ve hantal görünüme sahiptir. Ksanthos'da güreşçiler çıplaktır ve kulaklarında küçük delik bulunur. Isinda mezar dikmesi figürlerindeki güreşçiler Asur ve Babillerdeki gibi kısa don giymektedirler. Etrüsk duvar resimlerinde hem çılak hem de don giymiş güreşçiler vardır. Antik Yunanistan'da güreşçiler yağlı, hantal görünümlü, dolgun ve vücutları çıplaktır. Antik Mısırda tasvir edilen güreşçiler ise ince yapılıdırlar ve etek giymektedirler. Güreşçiler heykellerde genellikle çıplak tasvir edilmiştir.

Eski Çağ Ön Asya, Anadolu ve Afrika uygarlıklarına ait görseller incelendiğinde güreşin yapılış şekli ve güreşçilerin görünümlerinde benzerlikler ve farklılıklar tespit edilmiştir. Görseller arasındaki benzerliklerin nedenleri arasında sanatçıların algıları, tarihsel açıdan birbirlerine yakın dönemlerde resmedilmeleri ile göç ve ticaret gibi faaliyetlerin kültürel etkileri gösterilebilir. Görsellerden güreşlerin
\end{abstract}

Dr. Öğr. Üyesi, Sinop Üniversitesi Spor Bilimleri Fakültesi E-posta: mehmet.imamoglu@ outlook.com

Prof. Dr., Ondokuz Mayıs Üniversitesi Güzel Sanatlar Fakültesi Resim Bölümü, E-posta: gulteni@ omu.edu.tr 
kuralları yerine, güreşçilerin görünümleri ve kıyafetleri hakkında bilgiler elde edilebilmektedir.

Anahtar Kelimeler: Antik Çağ, Güreş, Spor Tarihi.

\title{
SIMILARITIES AND DIFFERENCES IN WRESTLING IMAGES OF ANCIENT ASIA, ANATOLIA AND AFRICAN CIVILIZATIONS
}

\begin{abstract}
This study aims to investigate the similarities and differences in the wrestling images of ancient pre-Asian, Anatolian and African civilizations.

In the paintings which were discovered in Mesopotamia and belonged to about $3000 \mathrm{BC}$, wrestlers are seen. Since ancient times, some themes, figures and characters have been depicted similar to each other. A similar situation is seen in wrestling figures. Some of the wrestlers are depicted with belt on their waist and some are without belt. Wrestler figures in the relief of the Ksanthos Wrestlers and in the grave of Isinda are similar. Wrestlers in figures have a large and cumbersome appearance. In Ksanthos, wrestlers are naked and have little holes in their ears. The wrestlers in the tombstones of Isinda wear short pants such as Assyrian and Babylonian. The wall paintings belonging to the Etruscans include naked or frost-wearing wrestlers. Wrestlers in ancient Greece are overweight, cumbersome looking and naked in their bodies. The wrestlers depicted in ancient Egypt are thin and wear skirts. Wrestlers are often depicted naked in sculptures.

When the visuals belonging to the ancient Asian, Anatolian and African civilizations were examined, similarities and differences were found in the style of wrestling and the appearance of the wrestlers. Among the reasons of the similarities between the visuals are the perceptions of artists, the historical portrayal of each other in recent periods, and the cultural effects of the activities such as migration and trade. Instead of the rules of wrestling, information about the appearance of wrestlers can be obtained.
\end{abstract}

\section{STRUCTURED ABSTRACT}

\section{Introduction}

Most of the ancient World Games are the first forms of modern sports. The Games and sports were held during the feast and festival days. There are countless similarities between civilizations that lived thousands of years ago and spread over tens of thousands of kilometers. Some of the spores made in the Bronze Age in Crete have been understood from the ruins that were previously made in Syria (Sipahi, 2001; Tekin ve Tekin,2014). Similar to the Lycian sports figures can be found in many different regions. Lycians have communicated with centers in the Mediterranean and Aegean regions through their natural harbors. Lycians were active in the Mediterranean in 2000 BC (Özüdoğru, 2008).The Kline which we see in both Etruscan and Anatolian tomb 
paintings is also seen in Helen, Egypt, Phoenician, Hittite, Syria and Assyrian (Dentzer, 1982).

The artifacts uncovered in the ancient cities of Isinda, Ksanthos, Aspendos and Patara were also found in different regions. In the planting dated $400 \mathrm{BC}$, belonging to Kherei, one of the largest lords of Xanththos; Was written to succeed in wrestling sport. The champion Tomb of the Roman Age, which was uncovered in Patara and exhibited at the Antalya Museum, is thought to belong to a wrestline. The culture that the ancient Greeks and many African tribes have created about martial arts has been transported throughout the generations (Koca ve İmamoğlu,2018).

A number of activities have become traditions over time and are reflected in figures. For example, wrestling, which was in the form of a competition or competition in the Ottoman state, became a traditional form in the following years and it became history as an ancestral sport of Turks (Şener ve İmamoğlu,2018).

In this study, it is aimed to determine the similarities and differences in the wrestling visuals of Ancient Asia, Anatolia and Africa civilizations. Literature was searched.

\section{Origin of Modern Wrestling}

Between the years 3600-2000 BC Sumerian 200 clay tablets, gold and silver artifacts, tombstones, temple architecture and the systematic examination of the Gilgamesh Epic as a result of the first time in the modern sense of sport was revealed by the Sumerians. It is thought that modern sports activities such as today emerged first during the Sumerian Civilization and these activities were carried to Ancient Greek Civilization through Hittites and Ancient Egyptians. (Evren, 1994). Among the reasons that motivate the sport in ancient pre-Asian civilizations, it is stated that the festivities are programmed and preparations for military tasks are at the forefront. (Korkmaz, 2013). The Hittites, who migrated to Anatolia in $2000 \mathrm{BC}$, competed with two-wheeled cars at the festivities organized in honor of the Sun God Tesup, poured from the blessed beer in the temple by the girls of Eti, sprinkled with flowers and sung songs. Wrestling competitions, sword games and horse races were also held at these festivals. The historical development of wrestling dates back to the Sumerians. Dest The Epic of Gilgamesh, written in cuneiform, statues and reliefs, is an important source of the first refereed competitions with music. In the old Babylonian Gilgamesh epic, a reference was made to the wrestling match between Gilgamesh and Enkidu and the wrestling match was depicted. The art works of $3000 \mathrm{BC}$ show pictures of wrestlers and boxing people. The text on clay tablets states that wrestling matches and competitions took place in the temple area along with program elements in religious celebrations. (Korkmaz,2013).

\section{Types of Wrestlers in Ancient Egypt}

Since $2000 \mathrm{BC}$, more than 4000 wrestling scenes have been found in Beni Hasan. There, sporting movements in couples and posture of athletes are depicted. It was seen that wrestlers wearing belts tried to turn their rivals' backs. In a relief at the Temple of Ramses III in Madinet Habou dating back to the 12th century BC, it is seen that the Egyptians and foreigners competed in wrestling and batting in front of the pharaoh. There is a scene showing an officer's intervention, and finally an Egyptian 
wrestler applying a suffocating yoke to his opponent and then celebrating his victory and declaring the winner. There are wrestling scenes and depictions of wrestlers wearing belts on the seals and reliefs of each period. The cuneiform texts in Mesopotamia point to different positions. The wrestlers hold the legs and the opponent's belt. So belt wrestling is an important part of the life of a warrior or hero. III. Ramses temple paintings depict international wrestling competitions and the Egyptians are always shown as winners. The wall paintings in Ptahotep and Tefu tombs show excellent grip techniques and working children. In addition, there are 60 kinds of grip techniques in Egypt, starting from simple, methodical, sequential and simple to complex. (Sporbilim, 2019More than 200 painted wrestling scenes, acrobatics and other activities at Sed festivals take place in the tombs and other scenes of Beni Hasan in the Middle Kingdom (around 2000 BC).

\section{Ancient Greece}

The philosopher Plato (427-347 BC) encouraged the youth of Athens to wrestle, and the historian Plutarch (about 46-120 BC) called wrestling the sport the "most technical and most challenging. A Greek wrestling guide, dating back to the first and second centuries $\mathrm{BC}$, confirmed Plutarch's views, revealing the complexity of the practices used by the Greeks to teach offensive and defensive tactics. The Helens have portrated their gods as young athletes in the art of sculpture. (Şener, 2018). For this reason, in ancient Greece, the figures are mostly naked and showy bodies. Sports have been used for peaceful purposes since ancient times (Yamaner ve İmamoğlu, 2018). For this reason, the peaceful feelings of artists may be reflected in visual.

\section{Result}

In ancient Asia, Asia and Africa, some similarities have been determined, such as the way of wrestling and the changes in the images of wrestlers according to the wrestling visuals. Migrations, travels and trade in similar ages and places may be effective in making similar images. There is also the effect of the similar perception of painters of people and animals originating from their own nature. More about the appearance and clothes of wrestlers, rather than the rules of wrestling by wrestlers.

Keywords: Ancient age, Wrestling, Sport History.

\section{Giriş}

Antik dünya oyunlarının çoğu modern sporların ilk şekilleridir. Oyunlar ve sporlar bayram ve festival günlerinde gerçekleştirilmiştir. Binlerce yıl önce yaşamış ve on binlerce kilometre alana yayılmış medeniyetler arasında sayısız benzerlik vardır. Binlerce yıl öncesinde antik kültürler bir şekilde birbirlerine bağlıymış gibidir (ancient-code, 2018). Ulusların mitolojilerini oluşturan öykü, inanış ve fikirler özgün olsa da, bazı temalar, figürler, karakterler birbirlerine çok benzerdir (onedio, 2019). Girit'te tunç çağında yapılan bazı sporların daha önce Suriye'de de yapıldığı elde edilen kalıntılardan anlaşılmıştır (Sipahi, 2001; Tekin ve Tekin,2014). Likyalılara ait sportif figürlerin benzerlerine birçok değişik bölgede rastlamak mümkündür. Likyalılar doğal limanları sayesinde Akdeniz ve Ege Bölgesindeki merkezler ile iletişim kurmuştur. Likyalılar milattan önce (MÖ) 2000 yıllarında Akdeniz'de etkin olmuşlardır (Özüdoğru, 2008). Hem Etrüsk hem de Anadolu mezar

\section{Turkish Studies - Social Sciences}

Volume 14 Issue 4, 2019 
resimlerinde gördüğümüz kline sahneleri sadece Helen dünyasında değil Mısır, Fenike, Hitit, Suriye ve Asur'da da karşımıza çıkmaktadır (Dentzer,1982). Isinda, Ksanthos, Aspendos ve Patara antik kentlerinde ortaya çıkarılan eserlerin benzerlerine farklı bölgelerde de rastlanmıştır. Ksanthos'un en büyük beylerinden biri olan Kherei'e ait MÖ 400 tarihli dikmede; beyin güreş sporunda başarılı olduğu yazılmıştır. Patara'da ortay çıkarılan ve Antalya Müzesi'nde sergilen Roma Çağı'na tarihli şampiyon lahdinin bir güreşçiye ait olduğu düşünülmektedir. Theronides adını taşıyan bu büyük sporcu döneminin en büyük yedi müsabakasında şampiyon olmuş ve kazandığı kupaları mezarının üstüne resmettirmiştir (antalyaekspres, 2019). Eski Yunanlıların ve birçok Afrika kabilesinin dövüş sporları hakkında oluşturduğu kültür kuşaklar boyunca taşınarak günümüze uzanmıştır (Koca ve İmamoğlu,2018). Bir takım faaliyetler zamanla gelenek haline gelmiş ve figürlere yansımıştır. Örneğin Osmanlı devletinde müsabaka veya yarışma şeklinde olan güreş daha sonraki senelerde geleneksel bir hale dönüşmüş ve Türklerin ata sporu olarak tarihe geçmiştir (Şener ve İmamoğlu,2018).

$\mathrm{Bu}$ çalışmada Eski Çağ Ön Asya, Anadolu ve Afrika uygarlıklarına ait güreş görsellerindeki benzerliklerin ve farklılıkların tespit edilerek incelenmesi amaçlanmaktadır. Literatür taraması yapılmıştır.

\section{Modern Güreşin Orijini}

MÖ 3600-2000 yılları arasında Sümerlere ait 200 kil tablet, altın ve gümüş eserler, mezar taşları, tapınak mimarisi ve Gılgamış Destanının sistemli incelenmesi sonucunda modern anlamdaki sporun ilk defa Sümerler tarafından ortaya konulduğu saptanmıştır. Günümüzdeki gibi modern spor faaliyetleri ilk olarak Sümer Medeniyeti sırasında ortaya çıktığı ve bu faaliyetlerin Hititliler ve Eski Mısırlılar aracıllı̆ı ile Eski Yunan Medeniyetine taşındığı düşünülmektedir (Evren, 1994). Antik Ön Asya medeniyetlerinde sporu motive eden nedenler arasında şenliklerin programlanması ve askeri görevler için hazırlıkların ön planda olması olarak belirtilir (Korkmaz, 2013). MÖ 2000 yıllarında Anadolu'ya göç eden Hititler, güneş tanrısı Teşup şerefine düzenledikleri şenliklerde iki tekerlekli araba ile yarışır birinci gelenin başına Eti kızları tarafından tapınakta kutsanmış biradan dökülür, üzerlerine çiçekler serpilir ve şarkılar söylenirdi. Bu şenliklerde güreş müsabakaları, kılıç oyunları ve at yarışları da yapılırdı. Güreşin tarihsel gelişimi Sümerler zamanına kadar uzanmaktadır. Çivi yazısı, heykeller ve kabartmalar halinde yazılmış "Gılgamış Destanı" müzik eşliğinde ilk hakemli müsabakaları ortaya çıkaran önemli bir kaynaktır. Eski Babil Gılgamış destanında Gılgamış ve Enkidu arasındaki güreş maçına bir atıfta bulunurken güreş karşılaşmasının betimlemesi yapılmıştır. MÖ 3000 yılına ait sanat eserlerinde güreşçilerin ve boks yapan insanların resimleri görülmektedir. Kil tabletleri üzerine metinde dini kutlamalarda program öğeleriyle birlikte güreş maçları ve müsabakalar tapınak bölgesinde gerçekleştiği belirtilir (Korkmaz,2013).

\section{Görsellerin Yorumlanması}

Şekil 1'de Mezopotamya'da ortaya çıkarılan stel üzerinde güreş ve boks müsabakası tasvir edilmiştir. MÖ yaklaşık 3000 yıllarına ait olduğu sanılmaktadır. Stel; yekpare dikili bir taştan oluşan yapıttır. Stel üzerinde güreşçi betimlemesi ilk olarak Irak'ta Badra civarında MÖ 2900 yılları civarında olduğu tahmin edilmektedir. Şekil 2'de bakır heykel görülmektedir. Bu bakır heykelin MÖ 3000-2600 yıllarına ait olduğu düşünülmektedir. Sümerlere aittir. Başlarında vazo, bellerinde ise kemer ile güreştikleri görülmektedir. MÖ 2600 yıllarına ait bir Sümer tapınağının kazılarında bulunan bronz bir eserde güreşçilerin karşılıklı olarak birbirleri tuttukları ve yenişmeye çalıştıkları Şekil 3'te tasvir edilmektedir. Vücut postürü egzersiz yapanlarda daha düzgün bir şekilde görünür (Yamak ve ark.,2018). Sporcuların çıplak resmedilmiş olmasında vücut güzelliklerinin dışa yansımasının etkisi olduğu söylenebilir veya sanatçlar bu durumu Yunan medeniyetinde çıplak resimlerle daha iyi ifade ettiklerinden figürler çıplak yapılmış olabilir. Çin'in batı sınırında Ordos denilen bölgede bulunan bir tunç tokası üzerinde bulunan figürde iki Alp'in güreş tuttukları görülüyor. Şekil 4'te görülen figürün MÖ 700'e ait olduğu sanılıyor. Bu figürlerde güreşçilerin iri yapılı ve sağlam bir bünyeye sahip bir 
şekilde betimlendikleri görülür. Şekil 2 ve 3'teki gibi bellerinde kemer ile güreşenlerin yanı sıra şekil 4 'teki gibi çılak güreşenler de tasvir edilmiştir.

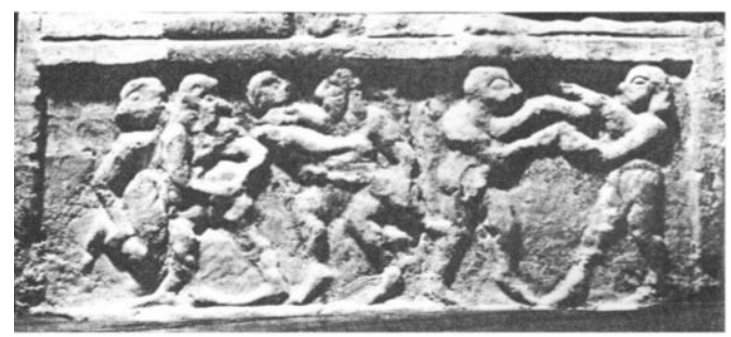

Şekil 1. Stel

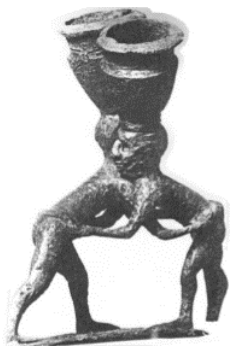

Şekil 2. Bakır heykel

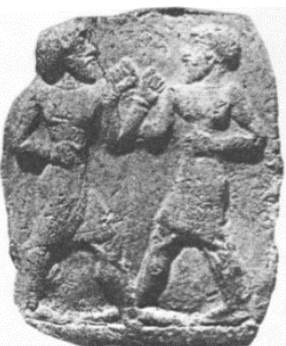

Şekil 3. Güreşçi kabartması

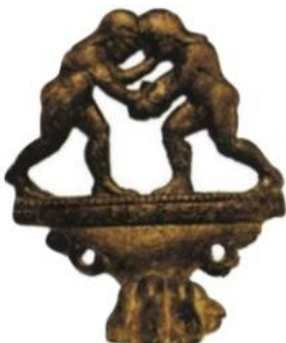

Şekil 4. Tunç kemer tokası

\section{Isinda Mezar Dikmesi}

Isinda mezar dikmesinin dört yüzünde farklı etkinlikler tasvir edilmiştir. Kuzey yüzünde şekil 5 'te yer alan güreş̧̧iler ve müzisyenler tasvir edilmiştir (Özüdoğru, 2008). Eser kısmen korunabilmiştir. Müzisyenler uzun kiyafetler ile tasvir edilmiştir.

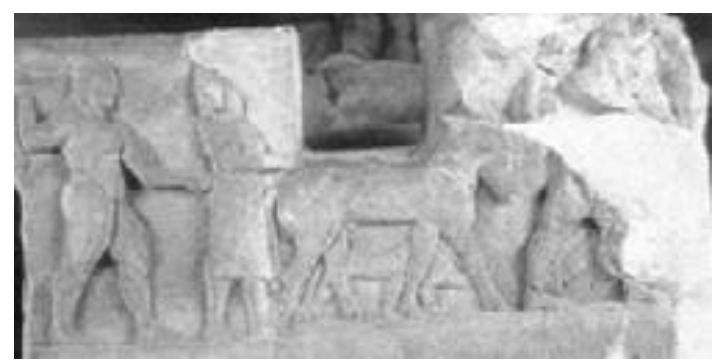

Şekil 5. Güreşçiler ve müzisyenler

\section{Ksanthos Güreșçiler Kabartması}

İstanbul Arkeoloji müzesinde sergilenen kireçtaşından yapılma blok üzerinde şekil 6'da görüldüğü üzere dört insan figürü tasvir edilmiştir. Bugün İstanbul Arkeoloji Müzesi'nde bulunan kabartmalı blok; yerel kireçtaşından yapılmıştır. Tasvirin sol kısmında el ense çeken iri yapılı iki güreşçi, sağ kısmında ise lyra çalan daha küçük yapılı iki müzisyen yer almaktadır (Özüdoğru,2008). 


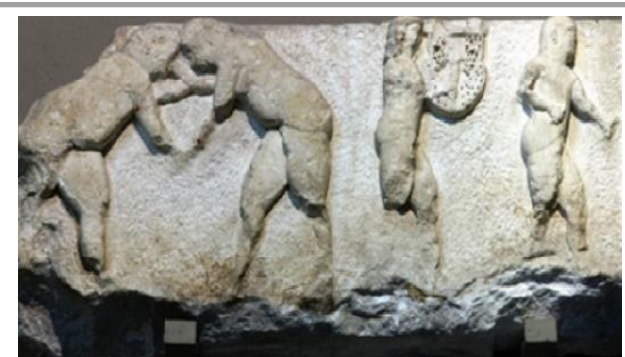

Şekil 6. Güreşçiler Kabartması

\section{Güreşçilerin Kısa Don Giymesi}

Şekil 7'de MÖ 550-500 aralığına ait Auguri mezar duvarındaki güreş sahnesi çizimi görülmektedir. Burada, biri sakallı, diğeri sakalsız iki çıplak güreşçi arasında, yarışmanın ödülü olan üç büyük bronz kazan durmaktadır. Helen sanatında ve Etrüsk mezarlarında gördüğümüz güreş ve boks karşılaşmalarındaki figürler çıplak olarak, Kızılbel güreş ve boks sahnelerinde ise şekil 8 'de görüldüğü gibi şort giymiş olarak tasvir edilmiştir (Yılmaz,2012).

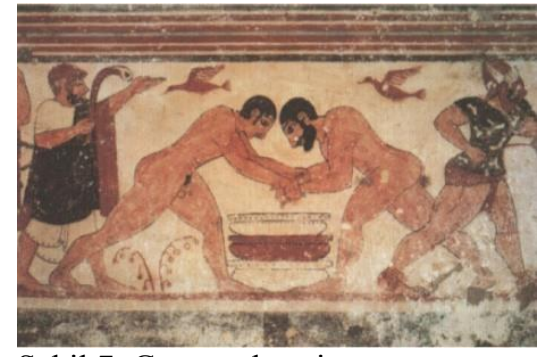

Şekil 7. Güreş sahnesi

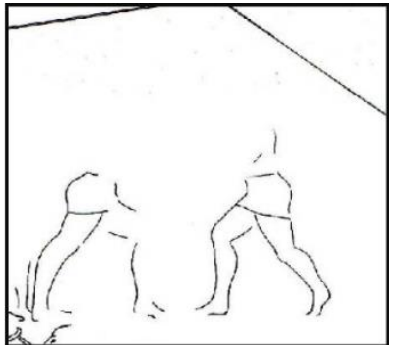

Şekil 8. Kızılbel güreş sahnesi

\section{Helen Vazo Resimlerinde ve Etrüsk Duvar Resimlerinde Güreşçi Görünüm Değişimi}

Güreş sahnelerini karşılaştırmak için Helen vazo resimlerinden ve Etrüsk duvar resimlerinden faydalanmak mümkündür. Şekil 9'da yer alan Helen örneklerinden amphoradaki güreşçilerin yağlı ve dolgun vücutları olduğu görülmektedir. Şekil 10'da Andokides tarafindan oluşturulan vazo üzerindeki resimde güreşçilerin daha sportif bir vücut yapısına sahip oldukları görülmektedir.

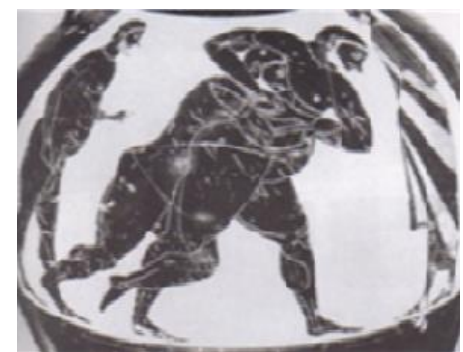

Şekil 9. Panathenaia Amphorası

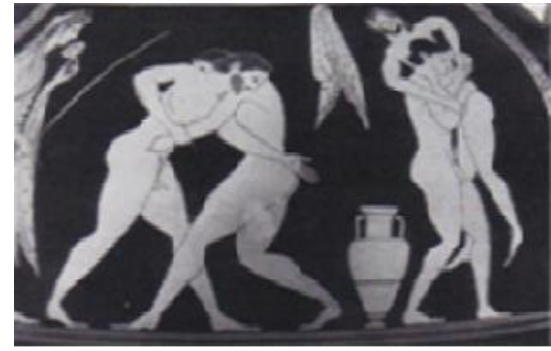

Şekil 10. Atina, Karınlı Amphora 


\section{Antik Mısırda Güreşçi Tipleri}

Tarihsel kökeni çok eskiye dayanan güreşler, çeşitli uygarlıkların kültür ve spor tarihinin bir parçası olmayı başarmıştır (Özdemir ve Çalışkan, 2018). Güreş, tarih boyunca uygarlıklar tarafından kabul görmüş ve gelişimini sürdürmüştür. Her medeniyetin sosyal, kültürel ve sportif özelliklerine göre güreşçi tipleri benzerlikler ve farklılıklar göstermektedir. Bu benzerlikler ve farklılıklar güreşçilerin giyimlerinde ve güreş oyunlarında görülebilmektedir. Ksanthos örneklerinde görülen güreşçi tipleri antik Mısırda farklıdır. Şekil 11'de Mısırda askeri oyunlar arasında göze çarpan güreşçiler ve sopalarla savaşanların ince yapılı oldukları görülmektedir. Şekil 12'de Mısırda Beni Hasan XV no'lu mezarın doğu duvarında resmedilen güreş sahnesinde güreşçilerin Ksanthosdaki güreşçiler kadar iri yapılı olmadığı ve o tarihlerde bile ne kadar çok değişik oyunları ihtiva edildiği görülmektedir. Kemer giyen güreşçilerin rakiplerinin sırtlarını çevirmeye çalıştıkları görülmüştür. Her döneme ait mühürlerin ve kabartmaların üzerinde yapılan güreş sahneleri ve kemerleri takan güreşçi tasvirleri bulunmaktadır. Mezopotamya'daki çivi yazılı metinler farklı duruşlara işaret eder. Güreşçiler bacaklardan ve rakip kemerinden tutarlar. O halde kemer güreşi bir savaşçının ya da kahramanın hayatının önemli bir parçasıdır. III. Ramses tapınağında bulunan resimlerde uluslararası güreş müsabakaları tasvir edilmektedir ve Misırlılar her zaman kazananlar olarak gösterilmektedir. Antik mısırda 60 civarında güreş tutuş tekniği basitten karmaşı̆̆a olacak şekilde mevcuttur (Sporbilim, 2019).

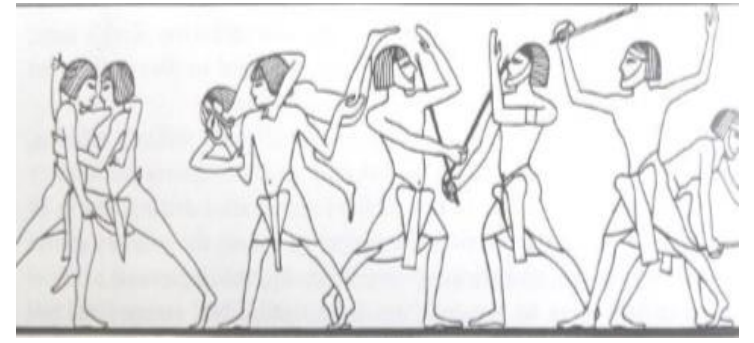

Şekil 11. Güreş ve tek sopa dövüşü

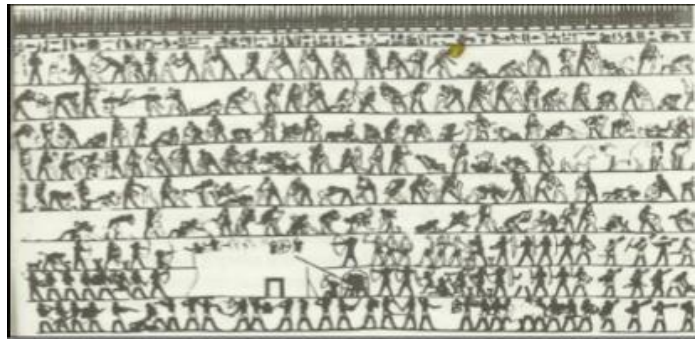

Şekil 12. Güreş sahnesi

\section{Antik Yunan}

Filozof Platon (MÖ 427-347), Atina'nın gençlerini güreşmeye teşvik etmiştir ve tarihçi Plutarch (Milattan sonra yaklaşık 46-120), güreş sporunu "en teknik ve en zorlu" olarak adlandırmıştır. MÖ birinci ve ikinci yüzyıla tarihlenen bir Yunan güreş rehberi, Plutarch'ın görüşlerini doğrulayarak, Yunanlıların hücum ve savunma taktiklerini öğretmek için kullandıkları uygulamaların karmaşıklığını gözler önüne sermiştir. Helenler Tanrılarını da genç sporcular olarak heykel sanatında canlandırmışlardır (Şener, 2018). Bu nedenle eski Yunanda figürler çoğunlukla çıplak ve gösterişli vücutlara sahiptir. Spor antik çağlardan itibaren barışçıl amaçlarla da kullanılmıştır (Yamaner ve İmamoğlu, 2018). Bu nedenle sanatçıların barışçıl duyguları görsellere yansımış olabilir.

\section{Sonuç}

Eski Çağ Ön Asya, Anadolu ve Afrika'da güreş görsellerine göre güreşlerin yapılış şekilleri ve güreşçilerin görüntülerinde değişimler olduğu gibi bazı benzerliklerde tespit edilmiştir. Benzerliklerin ve farklılıkların görülmesinde sosyal ve kültürel yapının etkili olduğu söylenebilir. Benzer görüntülerin yapılmasında birbirine yakın çağlarda ve yerlerdeki göçler, seyahatler ve ticaret etkili olabilir. Ayrıca ressamların kendi doğasından kaynaklı insanları ve hayvanları resmetme algılarının benzer olmasının da etkisi vardır. Güreş yapanların yaptıkları güreşlerin kurallarının nasıl olduğu konusundan çok güreşçilerin görüntüsü ve kıyafetleri üzerine bilgiler elde edilebilmektedir. 


\section{KAYNAKÇA}

Antalyaekspres, (12.04.2019). Erişim adresi: http://antalyaekspres.com.tr/yazi/zafer-varol/kirkpinar\%E2\%80\%99i-izlerken/36588

Ancient-code. (20.12.2018). Erişim adresi: https://www.ancient-code.com/the-mystery-handbag-ofthe-gods-depicted-in-sumer-america-and-gobekli-tepe/

Dentzer, J.M. (1982) Le Motif du banquet couché dans le Proche-Orient et le monde Grec du VIIe au Ve siécle avant J. C, Ecole Française, Roma.

Evren, M. ,(1994).Kapalı spor Salonları ve Diğer Spor Tesislerine Umumi Bir Bakış, İstanbul, Pulhan Matbaas1, s.5-25.

Koca F., İmamoğlu O.(2018). Sport History of Countries Other Africa Of Except Ancient Egypt, The Journal of International Social Research,Volume: 11 Issue: 61:1291-1304

Korkmaz S. (2013). Spor Müzelerinin İşlevleri ve Bir Spor Müzesi Taslağının Yönetsel Açıdan Oluşturulmas1, İstanbul Üniversitesi Sosyal Bilimler Enstitüsü Müze Yönetimi Programı Yüksek Lisans Tezi

Onedio, (03.02.2019), Erişim adresi: https://onedio.com/haber/dunya-mitolojilerinden-7-ilgincbenzerlik-405333

Özdemir, G., Çalışkan, V. (2018). Geleneksel Bir Sporun Coğrafyası: Türkiye'de Yağlı Güreşler (Kırkpınar-Edirne ve Çardak-Çanakkale Güreşleri). TÜCAUM 30. Yı1 Uluslararası Coğrafya Sempozyumu International Geography Symposium on the 30th Anniversary of TUCAUM 3-6 Ekim 2018 /3-6 October 2018, Ankara

Özüdoğru Ş. (2008). Arkaik Dönem Plastik Eserler Işığında Likya İkononografisinde Yerli ve Yabancı Unsurlar, Akdeniz Üniversitesi Sosyal Bilimler Enstitüsü Arkeoloji Anabilim Dalı Doktora Tezi, Antalya

Sipahi T. (2001). New Evidence From Anatolia Regarding Bull Leaping Scenes in the Art of the Aegean and the Near East. Anatolica, (27), s. 107-125.

Sporbilim,(18.03.2019).Erişim adresi: sporbilim.com/sayfa.asp?mdl=haber\&param=106

Şener O.A.(2018). Sporting Festivals and Effects in The Ancient Greek Civilization, The Journal of International Social Research, Volume: 11 Issue: 61:530-536

Şener O.A., İmamoğlu G. (2018). Wrestling's Activities and Reflections in The Ottoman Empire, Turkish Studies Social Sciences Volume 13/26, p. 1091-1106 DOI:10.7827/TurkishStudies.14301

Tekin A., Tekin G. (2014). Antik Yunan Dönemi: Spor ve Antik Olimpiyat Oyunları. Tarih Okulu Dergisi (TOD), Y11 7, Say1 XVIII, ss. 121- 140.

Yamak, B. İmamoğlu, O., İslamoğlu, İ., ÇEBİ, M., (2018). The Effects of Exercise on Body Posture, Turkish Studies Social Sciences, Volume 13/18, p. 1377-1388

Yamaner F., İmamoğlu O.,(2018). Antik Çağlarda Sporun Barışçıl Kullanımı ve Dinsel Etki, Akşemseddin Uluslararası İnsan, Toplum ve Spor Bilimleri Sempozyumu, Çorum

Yılmaz F. (2012). Arkaik Dönem Etrüsk ve Anadolu Mezar Resimlerinin Karşıslaştırılması, İsmail Fazılığlu Anı Kitabı, Trakya Üniversitesi Yayınları: (editör: Işık Şahin), , Bizim Büro Basımevi, Ankara, sh.231-240. 